\title{
Frihet: Mennesket, litteraturen og Russland
}

\author{
Svetlana Aleksijevitsj \\ Oslo: Kagge forlag 2018 \\ 103 sider. ISBN 9788248921967
}

Anmeldt av Martin Paulsen [seniorrådgiver, Diku, martpaulsen@hotmail.com]

Svetlana Aleksijevitsj har høstet anerkjennelse for sitt forfatterskap i lang tid. Hun skriver drivende godt, og hun tar opp grunnleggende menneskelige tema det er umulig å forholde seg likegyldig til. Med Nobelprisen i 2015 fikk hun plass på den litterære stjernehimmelen.

Noe av interessen for Aleksijevitsjs bøker skyldes at vi som lesere kan gjenkjenne hennes solide forankring i den russiske litterære tradisjonen. Dette manifesterer seg i den etiske forpliktelsen - hennes bøker tar stilling for det lille mennesket mot den statlige overmakten. Dette har vært et mantra i russisk litteratur i alle fall siden kritikeren Vissarion Belinskijs dager midt på 1800-tallet. Men det manifesterer seg også i hennes vilje til å ta på seg den autorative rollen som forfatterprofet - den forfatteren som ikke bare skriver gode bøker, men som også gjerne tar stilling til aktuelle sosiale og politiske spørsmål.

Manifestasjonene av den russiske litterære tradisjon kommer også til syne i denne utgivelsen, ikke minst i titlene som viser en vilje til å ta tak i de store spørsmålene. Frihet: Mennesket, litteraturen og Russland innledes av en introduksion til Aleksijevitsjs forfatterskap ved Erika Fatland og består av tre foredrag Aleksijevitsj har holdt de siste fem årene: hennes foredrag fra Litteraturhuset i Oslo i august 2017, «På sporet av det frie mennesket (den sovjetrussiske sjels historie)", en takketale i forbindelse med tildelingen av De tyske bokhandleres fredspris i oktober 2013, "Hvorfor har jeg steget ned i helvete?», og Nobelforedraget «Om et tapt slag» fra desember 2015.

Fatlands innledning er en fin kompliment til Aleksijevitsjs foredrag. Fatland understreker verdien av forfatterskapet og presenterer de fem utgivelsene i syklusen Utopiens stemmer. Mange lesere vil nok ha stor nytte av denne gjennomgangen, som er kortfattet, men engasjert. Det er også fint at Fatland trekker inn den historiske konteksten bøkene oppstod i; verdenshistoriens tannhjul har gjort mange omdreininger siden midten av 1980-tallet. Innledningen fungerer dermed som et godt utgangspunkt for å kunne få fullt utbytte av de påfølgende foredragene. 
Foredragene legger seg tett opp til forfatterskapet og bruker historiene om bøkene og deres tilblivelse som omdreiningspunkt for forfatterens betraktninger om hvorfor det har vært nødvendig for henne å skrive disse bøkene, og om hennes arbeidsprosess og metode.

Aleksijevitsj er en omstridt forfatter - ikke alle, og særlig ikke på hennes hjemtrakter, er enige med nobelkomiteen når det gjelder den litterære kvaliteten i hennes bøker. Litteraturviterne diskuterer sjangerbetegnelsen - er det sakprosa eller skjønnlitteratur, eller kanskje noe midt imellom? Selv om man skal være forsiktig med å gi forfatteren den endelige definisjonsmakten over egne verker, så gir hennes betraktninger et godt utgangspunkt for å analysere og diskutere tekstene.

Aleksijevitsj lar oss forstå hvorfor det har vært viktig for henne å skrive disse bøkene. Hun erkjente tidlig at kvinnenes fortellinger fra krigen skilte seg fra mennenes og den offisielle sovjetiske propagandaen. Hennes tekster blir dermed en måte å utfordre etablerte sannheter, slå sprekker i glansbildet, eller som hun selv foretrekker å si det: en måte å synliggjøre den menneskelige dimensjonen, som sjelens historiker.

Foredragene gir oss også god innsikt i arbeidet med kildene. Bøkene tar utgangspunkt i lange samtaler med et stort antall mennesker i Russland og nabolandene. Aleksijevitsj er opptatt av at hun ikke intervjuer, men samtaler. Nyansen skaper andre relasjoner - hun opererer ikke med intervjuobjekter, men samtalepartnere. Hennes beskrivelser av denne prosessen lar oss forstå at det er enormt tidkrevende, men at det er en metode som er nødvendig både for å oppnå fortrolighet og for å bryte gjennom veggen av propagandasjablonger. Hun antyder også at det vil være vanskelig for forfattere med en annen bakgrunn - enten de kommer fra en annen kultur eller generasjon - å oppnå den samme nærheten. Hennes samtalepartnere utbryter gjerne: «Bare et sovjetisk menneske kan forstå et annet sovjetisk menneske.»

I foredragene etablerer Aleksijevitsj også forbindelser mellom sitt eget litterære arbeid og den litterære kanon. Hun knytter særlig an til Dostojevskij, som omtales i alle tre foredragene. Slike referanser kan lett bli påtatte, men hos Aleksijevitsj inspirerer de til videre lesning og fungerer som døråpnere inn til den klassiske russiske litteraturen.

Tekstene er oversatt av Alf B. Glad og Hege Susanne Bergan. Begge har gjort en solid jobb og gitt foredragene en norsk språkdrakt som passer Aleksijevitsj godt.

Frihet som en egen bokutgivelse av disse foredragene finnes, slik jeg har forstått det, kun på norsk. Spørsmålet er om disse foredragene rettferdiggjør en egen bok. For selv om det er fint å kunne lese Aleksijevitsjs egne betraktninger om sitt forfatterskap, så er de tre foredragene ganske like, og flere av poengene hennes blir gjentatt i alle sammen. Dette gjelder for eksempel fortellingen om hvordan hun likte å lytte til landsbykonene da hun var barn. Dessuten vil jo også Aleksijevitsjs lesere kjenne igjen disse poengene fra de innledende betraktningene hun gjerne starter sine bøker med, slik som i Krigen har intet kvinnelig ansikt eller Slutten for det røde mennesket. Slik sett framstår dette som en utgivelse for spesielt interesserte. 